\title{
THE EFFECTS OF
}

DILTIAZEM (CRD-401) ON

THE MEMBRANE AND MECHANICAL PROPERTIES

\section{OF VASCULAR SMOOTH MUSCLES OF THE RABBIT}

\author{
YUSHI ITO, HIROSI KURIYAMA \& HIKARU SUZUKI
}

Department of Pharmacology, Faculty of Medicine, Kyushu University 60, Fukuoka, 812 Japan

1 The effects of diltiazem on electrical and mechanical properties of vascular smooth muscles of the rabbit were examined by various experimental procedures.

2 In the pulmonary artery, diltiazem $(0.1$ to $10 \mu \mathrm{g} / \mathrm{ml})$ did not modify the membrane potential $(-56 \mathrm{mV})$, length constant of the tissue $(1.47 \mathrm{~mm})$ or rectifying properties of the membrane. Diltiazem $(0.1$ to $10 \mu \mathrm{g} / \mathrm{ml})$ did not modify the membrane potential of the mesenteric artery $(-62.5 \mathrm{mV})$. 3 Diltiazem (1 to $10 \mu \mathrm{g} / \mathrm{ml}$ ) suppressed mechanical responses of pulmonary and mesenteric arteries induced either by direct stimulation of the muscle $(1.0 \mathrm{~s}$ pulse) or by neural activation $(0.5 \mathrm{~ms}$ pulse, $30 \mathrm{~Hz}$ and $10 \mathrm{~s}$ total duration). Diltiazem suppressed the contraction induced by nerve stimulation to a greater extent than that induced by direct muscle stimulation.

4 When the depolarization-contraction relationship of the smooth muscle of the pulmonary artery was observed by voltage clamp technique, diltiazem $(1$ to $10 \mu \mathrm{g} / \mathrm{ml})$ raised the critical membrane potential to evoke contraction from $5 \mathrm{mV}$ to $12 \mathrm{mV}$, and reduced the amplitude of contraction obtained at any given depolarization level.

5 In the pulmonary artery, diltiazem $(10 \mu \mathrm{g} / \mathrm{ml})$ suppressed $\mathrm{K}$-induced contraction and raised the mechanical threshold, while K-induced depolarization was not suppressed. Diltiazem (1 to $10 \mu \mathrm{g} / \mathrm{ml})$ also suppressed noradrenaline-induced contraction, raised the mechanical threshold and suppressed noradrenaline-induced depolarization.

6 The vasodilator actions of diltiazem on the vascular smooth muscle were compared to vasodilator actions observed with other Ca-antagonists.

\section{Introduction}

The roles of $\mathrm{Ca}^{2+}$ and actions of Ca-antagonists on excitation-contraction (E-C) coupling or pharmacocontraction (P-C) coupling mechanism in smooth muscle have been extensively investigated (Somlyo \& Somlyo, 1968; Hurwitz \& Suria, 1971; Fleckenstein, 1977).

In the vascular smooth muscle, the Ca-antagonists, verapamil, D 600 and nifedipine, suppressed influx of $\mathrm{Ca}^{2+}$ and release of $\mathrm{Ca}^{2+}$ from storage sites during the depolarization of the membrane produced either by excess $\mathrm{K}^{+}$or by chemical stimulation (Grün, Fleckenstein \& Byon, 1971; Grün \& Fleckenstein, 1972; Peiper \& Schmidt, 1972; Haušler, 1972; Weder \& Grün, 1973; Fleckenstein \& Byon, 1974; Golenhofen \& Hernstein, 1975). Recently, Fleckenstein, Nakayama, Fleckenstein-Grün \& Byon (1975) observed that the coronary vascular muscle of the pig was more sensitive to these Ca-antagonists than ordinary myocardial muscle fibres.
Diltiazem, (CRD-401), a new 1-5-benzothiazepine derivative, has been shown to be a potent coronary vasodilator and excitation-contraction decoupler in cardiac muscle cells, i.e. it produces a significant increase in coronary blood flow without increasing myocardial oxygen consumption, but causes a slight decrease in myocardial contractile force. Moreover, it is thought to exhibit a negative inotropic action on cardiac muscles by reducing the intracellular concentration of $\mathrm{Ca}^{2+}$ available for myocardial contraction (Sato, Nagao, Yamaguchi, Nakajima \& Kiyomoto, 1971; Nakajima, Hoshiyama, Yamashita \& Kiyomoto, 1975; 1976).

The effects of diltiazem on the electrical and mechanical activities of spontaneously active smooth muscle tissues such as guinea-pig taenia coli, rat myometrium and guinea-pig portal vein, were investigated by Magaribuchi, Nakajima \& Kiyomoto (1977a, b and c). They found that low concentrations of diltia- 
zem suppressed the spontaneously generated spikes without any appreciable change in the membrane potential, while electrical stimulation could still evoke the spike. However, high concentrations of diltiazem suppressed both electrical and mechanical activities. Moreover, diltiazem strongly suppressed the tonic response rather than the phasic response of $\mathrm{K}$-induced contracture. These observations suggest that diltiazem acts on the smooth muscle as a Ca-antagonist similar to verapamil and D 600 (Fleckenstein, 1977).

The present experiments were carried out to investigate the actions of diltiazem on the elctrical and mechanical properties of the rabbit pulmonary artery. Since this agent is thought to be an excitation-contraction decoupler in cardiac muscles and spontaneously active smooth muscle tissues, it was of interest to investigate the action of diltiazem on the electrically quiescent vascular smooth muscles.

Recently Casteels, Kitamura, Kuriyama \& Suzuki (1977a, b) and Ito, Kuriyama \& Suzuki (1977) studied the electrical and mechanical properties of the rabbit main pulmonary artery and elucidated the important roles of extra- and intracellular $\mathrm{Ca}^{2+}$ during the actions of chemical transmitters on the smooth muscle and also in $\mathrm{K}^{+}$-induced contractions ( $\mathrm{Su}$, Bevan \& Ursillo, 1964; Somlyo \& Somlyo, 1968).

The effects of diltiazem have now been observed on changes in the membrane potential, passive membrane properties, muscle contraction evoked by direct stimulation and nerve stimulation, and depolarization-contraction relationships of the pulmonary artery, an elastic vessel, and have been compared with the effects of this agent on the superior mesenteric artery, a resistance vessel.

\section{Methods}

Albino rabbits of either sex, weighing 2.5 to $3 \mathrm{~kg}$ (about one year old) were stunned and bled. The main pulmonary artery and superior mesenteric artery were excised and freed of connective tissue with the help of a dissecting microscope.

For the studies of the single cell activity and for the isometric tension recording, the tissues were cut in a circular direction (main pulmonary artery) to give a width of $2.0 \mathrm{~mm}$ and a length of about $10 \mathrm{~mm}$ or cut in a helical direction (superior mesenteric artery) to give a width of about $1.0 \mathrm{~mm}$ and a length of about $10 \mathrm{~mm}$. For the double sucrose gap method, the tissues from the pulmonary artery were cut in a circular direction to give a width of $0.5 \mathrm{~mm}$ and a length of about $10 \mathrm{~mm}$. For recording the membrane potential of single cells, conventional glass microelectrodes filled with $3 \mathrm{M} \mathrm{KCl}$ were inserted from the outer surface of the preparation. The resist- ances of the electrode varied from 30 to $80 \mathrm{M} \Omega$. The chamber for the microelectrode method had a volume of $2 \mathrm{ml}$ and was perfused at a rate of $3 \mathrm{ml} / \mathrm{min}$ at a temperature of 35 to $36^{\circ} \mathrm{C}$.

In order to investigate the passive properties of the tissue, the partition stimulating method was used as described by Abe \& Tomita (1968).

For simultaneous recordings of the membrane potential and tension, the double sucrose gap method was used. The chamber was a modification of that used originally by Rougier, Vassort, Garnier, Gargouil \& Coraboeuf (1969) consisting of five Lucite compartments separated by four diaphragms with holes in the centre. Each of the diaphragms between the central and terminal compartments were composed of three close fitting, slotted plates and were used to fix the preparation in position. The other two were rubber membranes and the muscle bundle was pulled through the close fitting holes and connected to the strain gauge for tension measurements. Therefore, the measured tension development was not strictly isometric. The central compartment, $0.55 \mathrm{~mm}$ in width, was perfused with Krebs solution or the test solution. The intermediate compartments, each $1 \mathrm{~mm}$ in width, were perfused with isotonic sucrose solution. The terminal compartments were relatively large and filled with isotonic $\mathrm{KCl}$ solution (Goto, Wada \& Saito, 1974). The circuit used for the voltageclamp experiments was essentially similar to that described by Anderson (1969). A high-voltage operational amplifier, Teledyne-Philbrick 1022, was used as the output amplifier of the feed-back circuit (Ohba, Sakamoto \& Tomita, 1975).

For measurement of tension developed, the strips excised from the mesenteric artery and pulmonary artery were mounted in the same chamber $(2 \mathrm{cc}$ in capacity) and two ring plates coated with silver-chloride were placed in the top and bottom of the organ bath to stimulate the tissues. The rate of perfusing was $3 \mathrm{cc} / \mathrm{min}$ at a temperature of $35^{\circ} \mathrm{C}$.

The Krebs solution (Bülbring \& Kuriyama, 1963) had the following composition (mM); $\mathrm{Na}^{+} 137.4, \mathrm{~K}^{+}$ 5.9, $\mathrm{Mg}^{2+} 1.2, \mathrm{Ca}^{2+} 2.5, \mathrm{Cl}^{-} 134.0, \mathrm{H}_{2} \mathrm{PO}_{4}^{-}$1.2, $\mathrm{HCO}_{3}^{-} 15.5$ and glucose 11.5 . The solution was aerated with $97 \% \mathrm{O}_{2}$ and $3 \% \mathrm{CO}_{2}$, and $\mathrm{pH}$ was maintained between 7.2 and 7.3. Excess $\mathrm{K}^{+} \mathrm{Krebs}$ solution was prepared by replacement of $\mathrm{NaCl}$ with an equivalent amount of $\mathrm{KCl}$, and $143.5 \mathrm{mM} \mathrm{K}^{+}$solution was prepared by replacement of $\mathrm{NaCl}$ and $\mathrm{NaHCO}_{3}$ with equivalent amounts of $\mathrm{KCl}$ and $\mathrm{KHCO}_{3}$, respectively. The following drugs were used at concentrations described in the results; tetrodotoxin (TTX; Sankyo Pharmac. Co. Ltd.), noradrenaline hydrochloride (Merck Pharmac. Co. Ltd.) and diltiazem (CRD-401, (+)-3-acetoxy-cis-2,3-dihydro-5(2-(dimethylamino)ethyl)-2( $p$-methoxyphenyl)-1,5-enzothiazepin-4(5H)one hydrochloride; Tanabe Pharmac. Co. Ltd.). 


\section{Results}

\section{Effects of diltiazem on the membrane properties}

The mean membrane potential of circular muscles of the rabbit main pulmonary artery was $-56.8 \pm 2.2$ $\mathrm{mV}(n=64)$, and neither electrical stimulation nor neurochemical substances changed the membrane potential. Application of diltiazem $(0.1$ to $10 \mu \mathrm{g} / \mathrm{ml})$ did not modify the membrane potential (in $10 \mu \mathrm{g} / \mathrm{ml}$; $-56.7 \pm 1.8 \mathrm{mV}, n=57$ ).

The mean membrane potential of smooth muscle cells of the mesenteric artery was similar to that observed in the pulmonary artery $(-59.6 \pm 2.8 \mathrm{mV}$, $n=56)$ and diltiazem ( 0.1 to $10 \mu \mathrm{g} / \mathrm{ml})$ did not modify the membrane potential level $(-58.7 \pm 2.5 \mathrm{mV}$ in 0.1 $\mu \mathrm{g} / \mathrm{ml} ;-60.1 \pm 2.3 \mathrm{mV}$ in $1 \mu \mathrm{g} / \mathrm{ml} ;-59.1 \pm 2.8 \mathrm{mV}$ in $10 \mu \mathrm{g} / \mathrm{ml}, n=24$ to 36 ).

When the current-voltage relationships were compared before and during application of $10 \mu \mathrm{g} / \mathrm{ml} \mathrm{dil-}$ tiazem at the same distance from the stimulating electrode $(0.3 \mathrm{~mm})$, an identical curve was obtained. As shown in Figure 1, the microelectrode was kept in the same cell before and during application of diltiazem. When outward current pulses $(3 \mathrm{~s})$ were applied to the membrane, the rectifying property of the membrane was shown before and during application of diltiazem. Applications of inward current pulse (3 s) showed a linear relationship up to $-85 \mathrm{mV}$ of hyperpolarization in both conditions. These results suggest that by treatment with diltiazem, ionic conductance of the membrane during depolarization and hyperpolarization was not affected.

To provide a further measure of any membrane changes, the length constant of the tissue was measured before and during application of diltiazem, i.e. the amplitude of the electrotonic potential was plotted on a log scale against the distance from the stimulating electrode, and the length constant was calculated from $\mathrm{e}^{-1}$ (Abe \& Tomita, 1968; Casteels et al., 1977a). In the control, the length constant of the tissue was $1.48 \pm 0.21 \mathrm{~mm}(\mathrm{n}=8)$, and in the presence of $10 \mu \mathrm{g} / \mathrm{ml}$ diltiazem, it was $1.46 \pm 0.28 \mathrm{~mm}$ $(n=4)$. These results show that the membrane resistance and membrane potential were not affected by treatment with diltiazem $(0.1$ to $10 \mu \mathrm{g} / \mathrm{ml})$.

\section{Effects of diltiazem on the mechanical activities}

Figure 2 shows the effects of diltiazem $(10 \mu \mathrm{g} / \mathrm{ml})$ on the mechanical responses induced by direct muscle stimulation and by nerve stimulation. The effects of diltiazem on the pulmonary artery and mesenteric artery were compared. To evoke mechanical responses, two forms of electrical stimulation were applied: one consisted of single pulses of $1.0 \mathrm{~s}$ duration $(O)$, the other consisted of trains of impulses

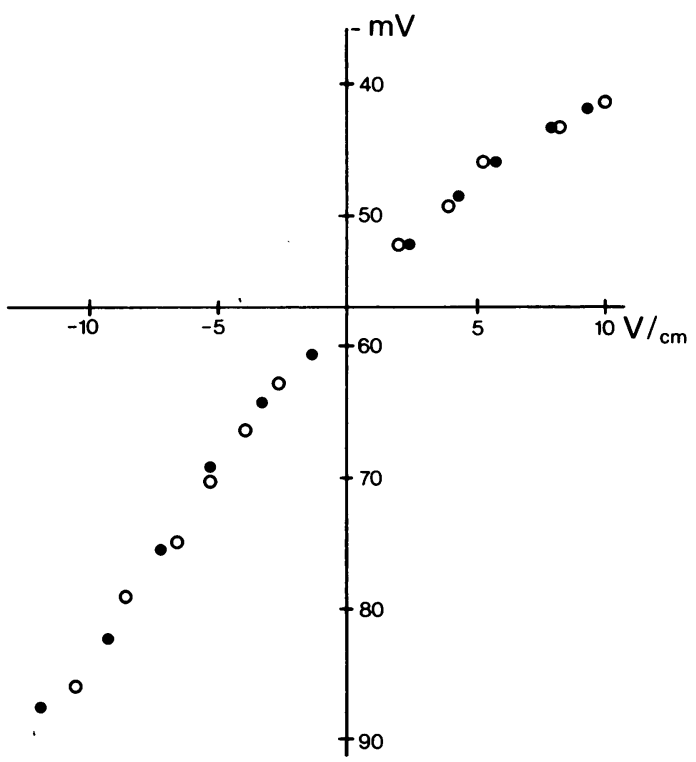

Figure 1 Current-voltage relationship of the same single smooth muscle of main pulmonary artery obtained before ( $\bullet$ ) and during application of diltiazem $10 \mu \mathrm{g} / \mathrm{ml}(\mathrm{O})$. The microelectrode was inserted in the same cell throughout the experiment. The distance between the stimulating plate and microelectrode was $0.3 \mathrm{~mm}$.

at $30 \mathrm{~Hz}$ and $0.5 \mathrm{~ms}$ pulse width applied for a period of $10 \mathrm{~s}(\bullet)$. The current intensities in both types of stimulation were supramaximal. When the tissue was stimulated by single pulses of various durations the maximum twitch was recorded by application of a pulse that was more than $0.75 \mathrm{~s}$ in duration. Therefore, single pulses of $1.0 \mathrm{~s}$ duration were used in the present experiments. Following pretreatment with tetrodotoxin $(0.1 \mu \mathrm{g} / \mathrm{ml})$, the mechanical responses induced by the long pulse stimulation were not affected but those induced by the short pulse stimulation were almost completely prevented. This means that the former was generated by direct muscle stimulation and the latter was induced by the peripheral nerve stimulation (Figure 2a, b). When the long and short pulse stimulations were applied to both tissues before and during application of diltiazem $(1$ and $10 \mu \mathrm{g} / \mathrm{ml})$, the mechanical response induced by direct muscle stimulation was reduced to $70 \%$ of the control in the mesenteric artery and to $50 \%$ of the control in the pulmonary artery (in $10 \mu \mathrm{g} / \mathrm{ml}$ diltiazem, $n=5$ ), and the mechanical response induced by nerve stimulation was reduced to $20 \%$ of the control in the mesenteric and to $10 \%$ in the pulmonary artery $(10 \mu \mathrm{g} / \mathrm{ml}, n=5)$. 
a

b

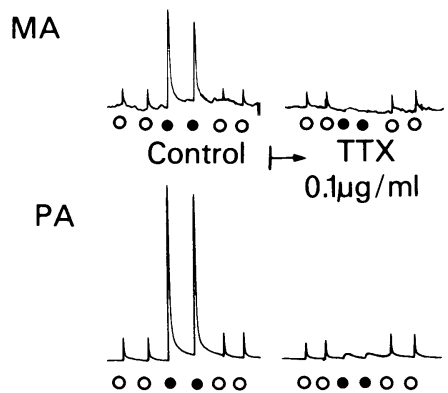

C

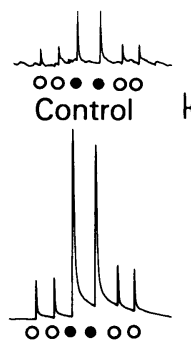

d

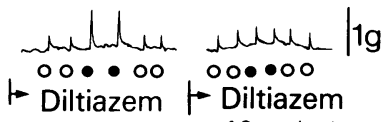

$1 \mu \mathrm{g} / \mathrm{ml}$

$10 \mu \mathrm{g} / \mathrm{ml}$

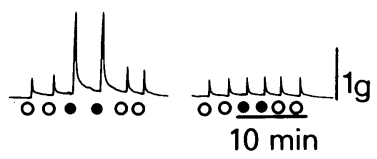

Figure 2 Effects of diltiazem on the contractions of the superior mesenteric artery (MA) and the main pulmonary artery (PA) induced by direct muscle stimulation and by nerve stimulation: (O) 1st pulse stimulation; (๑) $0.5 \mathrm{~ms}$ pulse in duration, $30 \mathrm{~Hz}$ in frequency and $10 \mathrm{~s}$ in stimulus duration. (a) Control; (b) after $10 \mathrm{~min}$ tetrodotoxin $(0.1 \mu \mathrm{g} / \mathrm{ml})$ treatment; (c) control; (d and e) after 10 min diltiazen 1 $\mu \mathrm{g} / \mathrm{ml}$ and $10 \mu \mathrm{g} / \mathrm{ml}$ treatment, respectively.

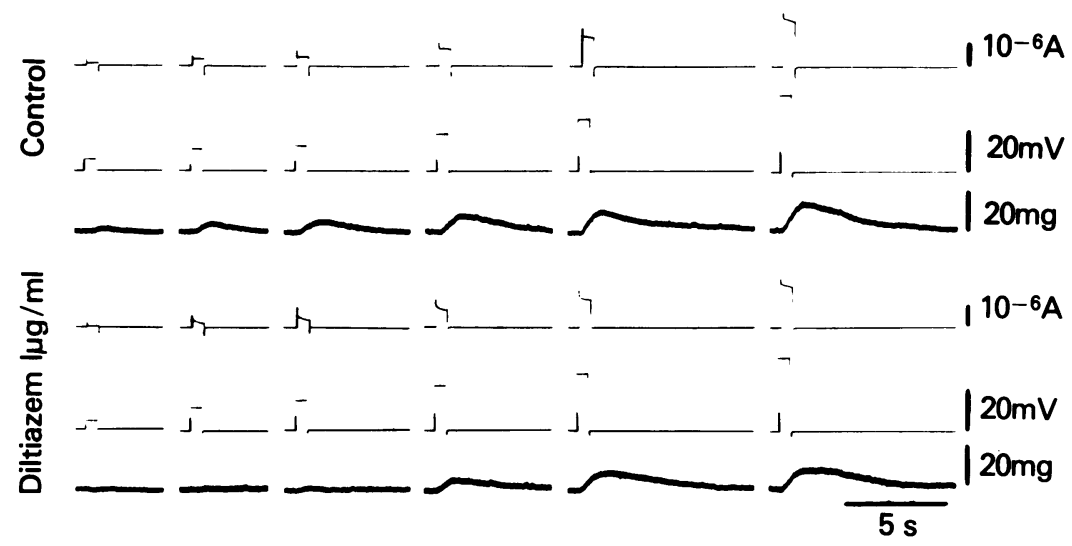

Figure 3 Effects of diltiazem $(1 \mu \mathrm{g} / \mathrm{ml})$ on the depolarization-induced contraction in the smooth muscles of the main pulmonary artery. The membrane was depolarized ( $1 \mathrm{~s}$ in duration) in steps with the voltage clamp procedure before and during application of diltiazem. The membrane potential in this preparation measured by the double sucrose gap method was $45 \mathrm{mV}$. Top record: current; middle record; step depolarization of the membrane; bottom record; contraction of muscle.

Effects of diltiazem on the contraction induced by depolarization

The effects of diltiazem on the depolarization-induced contraction in the pulmonary artery were observed by voltage clamp procedures. In order to avoid the decline of the response induced by deterioration of the tissue following the application of strong depolarization during the clamp procedures, the above relationships were always compared before and after application of diltiazem, and the results are given only for tissues that showed good reversibility. In this experiment, electrical currents were not investigated in detail. However, early inward current was not observed during application of depolarization. This phenomenon agreed with the result obtained by the microelectrode method or current clamp method. A typical example is shown in Figure 3. The resting membrane potential in this double sucrose gap method was $45 \mathrm{mV}$. Increased depolarization $(1 \mathrm{~s}$ in duration) enhanced the mechanical response proportionally. Following application of diltiazem the mechanical responses were reduced at any given depolarization of the membrane and the reduction depended on the concentration of diltiazem. When the relationships between the depolarization and the maximum amplitude of the contraction evoked in the pulmonary artery were plotted before, during and 

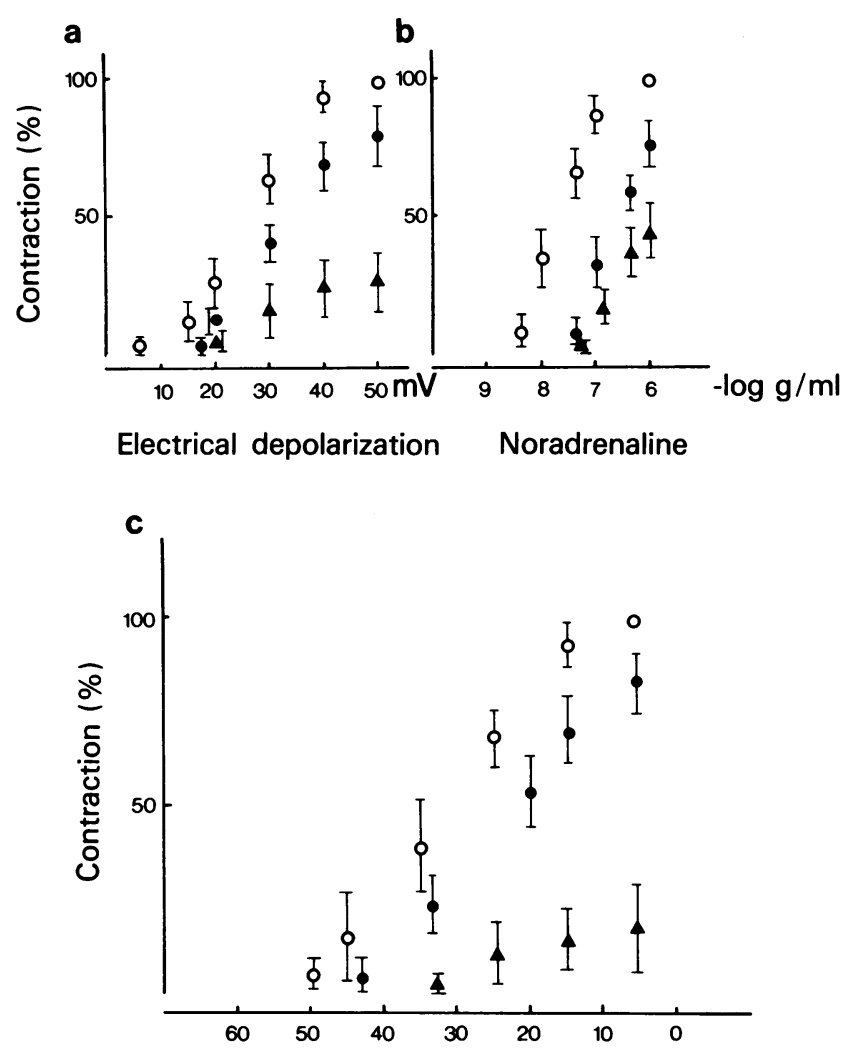

Membrane potential in various $[\mathrm{K}]_{\circ}(-\mathrm{mV})$

Figure 4 Effects of diltiazem $(1 \mu \mathrm{g} / \mathrm{ml}$ and $10 \mu \mathrm{g} / \mathrm{ml})$ on the depolarization-induced contraction and noradrenaline-induced contraction in smooth muscle cells of the pulmonary artery. (a) Voltage clamp procedures were used to obtain the depolarization-contraction relationship. The membrane potentials varied between 45 and $38 \mathrm{mV}$ in 5 tissues. Contractions are shown relative to $100 \%$ contraction which was taken as that evoked by $50 \mathrm{mV}$ step depolarization (1 s pulse). (b) Various concentrations of noradrenaline (1 $\mathrm{ng}$ to $1 \mu \mathrm{g} / \mathrm{ml}$ ) were used to evoke the contraction; $100 \%$ contraction was taken as that evoked

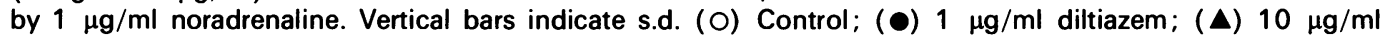
diltiazem. (c) Various concentrations of $\mathrm{K}^{+}$were used to depolarize the membrane. The membrane potential was measured by the microelectrode method; $100 \%$ contraction was taken as that induced by 143.5 $\mathrm{mM} \mathrm{K}$ at the membrane potential of $-5 \mathrm{mV}$. $\mathrm{K}^{+}$concentrations varied from $11.8 \mathrm{mM}$ to $143.5 \mathrm{~mm}$. The mean membrane potential levels were calculated in various concentrations of $\mathrm{K}^{+}(n=30$ to 45) in 4 different preparations. The contractions were recorded from different preparations $(n=5)$ in appropriate

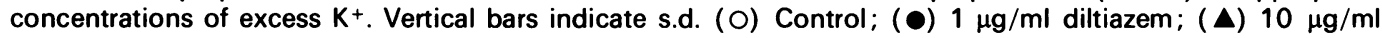
diltiazem.

after application of diltiazem, the significant features of the diltiazem action could be elucidated: i) in the control, the minimum depolarization of the membrane to elicit contraction was $5 \mathrm{mV}$; ii) in the presence of $1 \mu \mathrm{g} / \mathrm{ml}$ diltiazem, the minimum depolarization level to produce contraction was increased to $11 \mathrm{mV}$, and the depolarization-response curve was displaced to right; iii) an increased concentration of diltiazem $(10 \mu \mathrm{g} / \mathrm{ml})$ raised the minimum depolarization level $(13 \mathrm{mV})$ only slightly compared to that in- duced by $1 \mu \mathrm{g} / \mathrm{ml}$ but greatly reduced the mechanical response. In the presence of diltiazem $(10 \mu \mathrm{g} / \mathrm{ml})$, the amplitude of the contraction reached a maximum with a depolarization of $40 \mathrm{mV}$ and the reduction of the contraction induced by diltiazem $(10 \mu \mathrm{g} / \mathrm{ml})$ could not be overcome by further depolarization of the membrane.

Figure $4 \mathrm{a}$ shows the effects of diltiazem $(1$ and 10 $\mu \mathrm{g} / \mathrm{ml})$ on the mean depolarization-contraction relationships of smooth muscle cells of the pulmonary 
artery $(n=5)$. The membrane potentials recorded by the double sucrose gap method varied from 45 to $39 \mathrm{mV}$. The increase in tension measured at $50 \mathrm{mV}$ depolarization was taken as $100 \%$ tension. When the contraction evoked by $50 \mathrm{mV}$ depolarization was compared with that in 1 or $10 \mu \mathrm{g} / \mathrm{ml}$ diltiazem, the contraction was reduced to $80 \%$ or to $27 \%$, respectively $(n=5)$. The threshold for a contraction was raised from $5 \mathrm{mV}$ depolarization $(n=5)$ to $17 \mathrm{mV}$ by $1 \mu \mathrm{g} / \mathrm{ml}$ and to $20 \mathrm{mV}$ by $10 \mu \mathrm{g} / \mathrm{ml}(n=5)$. To observe further the relationship between the depolarization and contraction in the presence of diltiazem, in conventional ways, contraction was evoked by either excess $K$ or noradrenaline treatment. Figure $4 \mathrm{~b}$ shows the effects of diltiazem on noradrenalineinduced contraction of smooth muscle cells of the pulmonary artery. In the pulmonary artery, the minimum concentration of noradrenaline to evoke the contraction was $2.5 \mathrm{ng} / \mathrm{ml}$. Application of 1 and 10 $\mu \mathrm{g} / \mathrm{ml}$ diltiazem raised the minimum effective concentration of noradrenaline to $50 \mathrm{ng} / \mathrm{ml}$ and to $0.1 \mu \mathrm{g} / \mathrm{ml}$ $(n=5)$, respectively. When the $1 \mu \mathrm{g} / \mathrm{ml}$ noradrenaline-induced contraction was taken as $100 \%, 1 \mu \mathrm{g} / \mathrm{ml}$ diltiazem reduced the response to $75 \%$ of the control value and $10 \mu \mathrm{g} / \mathrm{ml}$ to $41 \%(n=5)$.

When the effects of diltiazem on the noradrenalineinduced depolarization were observed in the pulmonary artery, $0.1 \mu \mathrm{g} / \mathrm{ml}$ and $1 \mu \mathrm{g} / \mathrm{ml}$ noradrenaline depolarized the membrane from $-56.4 \pm 2.1 \mathrm{mV}$ to $-51.5 \pm 2.4 \mathrm{mV}(n=30)$ and to $-48.3 \pm 2.4 \mathrm{mV}$ $(n=20)$, respectively. By treatment with $10 \mu \mathrm{g} / \mathrm{ml} \mathrm{dil-}$ tiazem during application of noradrenaline, the membrane was repolarized to nearly the resting membrane potential level (in Krebs solution; $-55.3 \pm 2.6 \mathrm{mV}$, $n=30$ and in $0.1 \mu \mathrm{g} / \mathrm{ml}$ noradrenaline with $10 \mu \mathrm{g} / \mathrm{ml}$ diltiazem; $-55.2 \pm 3.4 \mathrm{mV}, n=24)$. This result indicated that diltiazem did not change the membrane potential in Krebs solution but it did suppress the noradrenaline-induced depolarization.

Figure $4 \mathrm{c}$ shows the effects of diltiazem on the $\mathrm{K}$-induced contraction observed in the pulmonary artery. The relationships between depolarization and contraction induced by various concentrations of $\mathrm{K}^{+}$ were plotted before and during application of diltiazem. The membrane potential was measured by the microelectrode method. When the membrane was depolarized from $-55.9 \pm 2.4 \mathrm{mV}(n=30)$ to $-50.1 \pm 3.1 \mathrm{mV}(n=30)$ by $17.7 \mathrm{mM} \mathrm{K}^{+}$, a contraction was evoked. The maximum depolarization was produced by $143.5 \mathrm{mM} \mathrm{K}^{+}(-4.8 \pm 0.3 \mathrm{mV}, n=20)$ but a near maximum contraction had already appeared at $-16 \pm 1.9 \mathrm{mV}(n=20)$ in $118 \mathrm{mM} \mathrm{K}^{+}$. In the presence of diltiazem $(1 \mu \mathrm{g} / \mathrm{ml})$ the mechanical threshold was raised from $5.8 \mathrm{mV}$ to $16.4 \mathrm{mV}$ $(-40.3 \pm 1.8 \mathrm{mV}, n=30,4$ preparations $)$, and an increased concentration of diltiazem $(10 \mu \mathrm{g} / \mathrm{ml})$ further raised the mechanical threshold to $24.5 \mathrm{mV}$
$(-31.4 \pm 1.8 \mathrm{mV}, n=30,4$ preparations). The membrane potential measured in various concentrations of excess $\mathrm{K}^{+}$was hardly affected by treatment with diltiazem (e.g., in $10 \mu \mathrm{g} / \mathrm{ml}$ diltiazem; $-5.2 \pm 0.4 \mathrm{mV}$ in $143.5 \mathrm{mM} \mathrm{K}^{+}, n=20$ ). The contraction induced by depolarization was slightly suppressed by $1 \mu \mathrm{g} / \mathrm{ml}$ diltiazem and was markedly reduced by $10 \mu \mathrm{g} / \mathrm{ml}$ to $18 \%$ of the control value compared with a $-5 \mathrm{mV}$ depolarization in $143.5 \mathrm{mM} \mathrm{K}^{+}(n=5)$. In the pulmonary artery, $\mathrm{Na}^{+}$-free or $\mathrm{Na}^{+}$-deficient $(<5 \mathrm{~mm})$ solution produced contraction without depolarization of the membrane (Casteels et al., 1977b) and therefore, $143.5 \mathrm{mM} \mathrm{K}^{+}\left(\mathrm{Na}^{+}\right.$-free)-induced contraction may be made up of two different components. However, 118 $\mathrm{mM} \mathrm{K}^{+}\left(15.5 \mathrm{mM} \mathrm{Na}{ }^{+}\right)$-induced contraction was considerably reduced by $10 \mu \mathrm{g} / \mathrm{ml}$ diltiazem to $20 \%$ of the value obtained at $-16 \mathrm{mV}$ depolarization in 118 $\mathrm{mM} \mathrm{K}^{+}(n=4)$.

\section{Discussion}

In the normal and depolarized isolated cardiac papillary muscle, diltiazem antagonized $\mathrm{Ca}^{2+}$ and thus caused a reduction in the contractile force. The antagonistic ratio of diltiazem to $\mathrm{Ca}^{2+}$ was estimated to be approximately 1:100 (Nakajima et al., 1975; 1976) In the spontaneously active visceral smooth muscles, namely, taenia coli and rat myometrium, diltiazem $\left(2.2 \times 10^{-6} \mathrm{M}\right)$ may reduce the transmembrane influx of $\mathrm{Ca}^{2+}$ during the active state of the membrane, because this agent suppressed the number and amplitude of the spikes in the burst discharges. Moreover, the changes in various parameters of the action potential caused by diltiazem were reversed by the addition of $\mathrm{CaCl}_{2}$. However, low concentrations of diltiazem did not suppress the electrically evoked spike (Magaribuchi et al., 1977a, b).

In spite of the lack of spike generation mechanism in smooth muscles of the pulmonary artery, diltiazem reduced the depolarization-induced contraction and raised the threshold for a mechanical response. Recently, Ito et al. (1977) discussed the roles of $\mathrm{Ca}^{2+}$ in the generation of contraction in the pulmonary artery during electrical depolarization and they concluded that the influx of extracellular $\mathrm{Ca}^{2+}$ might play a primary role in the generation of contraction induced either by electrical or by excess $\mathrm{K}^{+}$stimulation. Presumably this agent suppresses the mobilization of $\mathrm{Ca}^{2+}$ during depolarization, thus causing a smaller increase in intracellular free $\mathrm{Ca}^{2+}$. It is also postulated that diltiazem suppresses the release of $\mathrm{Ca}^{2+}$ from the storage sites during noradrenalineinduced contraction, because noradrenaline at a high concentration $(>50 \mathrm{ng} / \mathrm{ml})$ is known to release stored $\mathrm{Ca}$ and also to increase the influx of $\mathrm{Ca}^{2+}$ (Casteels et al., 1977b). Diltiazem neither modified the mem- 
brane potential nor changed the membrane conductance. However, noradrenaline-induced depolarization was reduced. Presumably reduction of this depolarization by diltiazem might be related to inhibition of $\mathrm{Ca}^{2+}$ mobilization and $\mathrm{Na}^{+}$permeability. Diltiazem, on the other hand, did not suppress the depolarization induced by excess $\mathrm{K}^{+}$solution. Presumably diltiazem may possess some selectivity in its action as a Ca-antagonist.

From the effects of diltiazem on the mechanical responses induced by electrical stimulation, it is postulated that this agent acts not only on the muscle cell but also on the chemical transmitter releasing mechanism from the nerve terminals, because the contraction induced by nerve stimulation rather than that induced by direct muscle stimulation was strongly suppressed. In the neuromuscular transmission process, $\mathrm{Ca}^{2+}$ acts as the mobilizer of the vesicles distributed in the synaptic nerve terminals (Katz \& Miledi, 1967). The suppression of chemoreceptor sensitivity to the transmitter substance cannot be ruled out from the present experiments.

Measurement of the passive characteristics of the membrane in the mesenteric artery was difficult due to technical problems. However, the changes in the membrane potential and in the mechanical responses induced by electrical and chemical stimulation were very similar to those obtained from the pulmonary artery. Therefore, diltiazem may have similar actions on the elastic and resistance vessels as a vasodilator. These actions of diltiazem on vascular smooth muscles were similar in effect to those of the socalled Ca-antagonists, D 600, verapamil and nifedi-

\section{References}

ABE, Y. \& TOMITA, T. (1968). Cable properties of smooth muscle. J. Physiol., 196, 87-100.

ANDERSON, N.C. (1969). Voltage-clamp studies on uterine smooth muscle. J. gen. Physiol., 54, 145-165.

BÜLBRING, E. \& KURIYAMA, H. (1963). Effects of changes in the external sodium and calcium concentrations on spontaneous electrical activity in smooth muscle of guinea-pig taenia coli. J. Physiol., 166, 29-58.

CASTEELS, R., KITAMURA, K., KURIYAMA, H. \& SUZUKI, H. (1977a). The membrane properties of the smooth muscle cells of the rabbit main pulmonary artery. $J$. Physiol., 271, 41-61.

CASTEELS, R., KITAMURA, K., KURIYAMA, H. \& SUZUKI, H. (1977b). Excitation-contraction coupling in the smooth muscle cells of the rabbit main pulmonary artery. J. Physiol., 271, 63-79.

FLECKENSTEIN, A. (1977). Specific pharmacology of calcium in myocardium, cardiac pacemakers, and vascular smooth muscle. A. Rev. Pharmac. Tox., 17, 149-166.

FLECKENSTEIN, A. \& BYON, Y.K. (1974). Prevention by Ca-antagonistic compounds (verapamil, D 600) of coronary smooth muscle contractures due to treatment pine on various visceral muscles (Fleckenstein, 1977), although the actions of diltiazem may not be identical to those of the Ca-antagonists. For example, Golenhofen (1976) classified the contraction evoked in the smooth muscle into $\mathrm{P}$ and $\mathrm{T}$ systems using Ca-antagonists, i.e. he proposed that chemically different systems for Ca-activation might exist in the membrane, referred to as $\mathrm{P}$ and $\mathrm{T}$ systems; the former being used for producing phasic contraction and being blocked by verapamil, D 600 and nifedipine, and the latter for tonic contraction and not blocked by the above agents but suppressed by treatment with nitroprusside.

Since smooth muscle of the pulmonary artery is electrically quiescent, the contraction evoked in this tissue might be classified as a $\mathrm{T}$ system dominant tissue. Diltiazem reduced the contraction evoked by electrical depolarization, excess $\mathrm{K}^{+}$or noradrenaline. Moreover, the threshold depolarization to evoke a contraction was raised. Similar effects of diltiazem were also observed on contraction evoked in the portal vein of rabbit, categorized as the $\mathbf{P}$ system (Ito, Suzuki \& Kuriyama, unpublished observations).

This means that diltiazem shows Ca-antagonistic actions on smooth muscle due to suppression of mobilization of $\mathrm{Ca}^{2+}$ and that the mechanism of these actions differs slightly from those described for the other Ca-antagonists, D 600, verapamil and nifedipine.

This work is supported by grants from the Ministry of Education in Japan (148094). with cardiac glycosides. Naunyn-Schmiedebergs Arch. Pharmac., 282 (suppl.): R. 20.

FLECKENSTEIN. A.. NAKAYAMA, K., FLECKENSTEINGRÜN, G. \& BYON, Y.K. (1975). Interactions of vaso active ions and drugs with $\mathrm{Ca}$-dependent excitationcontraction coupling of vascular smooth muscle. In Calcium Transport in Contraction and Secretion. ed. Carafoli E. et al. pp. 556-566 Amsterdam: NorthHolland.

GOLENHOFEN, K. (1976). Theory of P and T systems for calcium activation in smooth muscle. In Physiology of Smooth Muscle. ed. Bülbring, E \& Shuba, M.F. pp. 197-202 N.Y.: Raven Press.

GOLENHOFEN, K. \& HERNSTEIN, N. (1975). Differentiation of calcium activation mechanism in vascular smooth muscle by selective suppression with verapamil and D 600. Blood Vessels, 12, 21-37.

GOTO, M., WADA, Y. \& SAITO, M. (1974). Tension components and tension fall of the bullfrog atrial muscle during depolarization. Jap. J. Physiol., 24, 359-375.

GRÜN, G. \& FLECKENSTEIN, A. (1972). Die electromechanische Entkoppelung der glatten Gefäss-Musku- 
latur als Grundprinzip der Coronardilatation durch 4-(2'-Nitrophenyl)-2-6-dimethyl-1, 4-dihydropyridin3.5-dicarbon säure-dimethyl ester (Bay a1040. Nifedipine). Arzneim. Forsch., 22, 334344.

GRÜN. G., FLECKENSTEIN. A. \& BYON, Y.K. (1971). Caantagonism, a new principle of vasodilation. Proc. Int. Union Physiol. Sci. XXV. Int. Congr. Munich IX, 221.

HAUŠLER, G. (1972). Differential effect of verapamil on excitation-contraction coupling in smooth muscle and on excitation-secretion coupling in adrenergic nerve terminals. J. Pharmac. exp. Ther., 180, 672-682.

HURWITZ. L. \& SURIA. A. (1971). The link between agonist action and response in smooth muscle. A. Rer. Pharmac., 11, 303-326.

ITO, Y., KURIYAMA, H. \& SUZUKI. H. (1977). On the roles of calcium ion during potassium induced contracture in the smooth muscle cells of the rabbit main pulmonary artery. Jap. J. Phisiol., 27, 755-770.

KATZ. B. \& MILEDI. R. (1967). The timing of Ca action during neuromuscular transmission. J. Physiol.. 189, 535-544.

MAGARIBUCHI. T., NAKAJIMA, H. \& KIYOMOTO. A. (1977a). Effects of diltiazem and Lauthanum ion on the potassium contracture of isolated guinea pig smooth muscle. Jap. J. Pharmac., 27, 333-339.

MAGARIBUCHI. T.. NAKAJIMA. H.. TAKENAGA. H. \& KIYOMOTO. A. (1977b) Effect of diltiazem on the transmembrane potential of isolated guinea pig taenia coli. Jap. J. Pharmac.. 27, 319- 322.

MAGARIBUCHI. T., NAKAJIMA, H. \& KIYOMOTO, A. $(1977 \mathrm{c})$. Effects of diltiazem on electrical and mechanical activities of isolated guinea pig taenia coli. Jap. J. Pharmac.. 27, 361-369.

NAKAJIMA. H.. HOSHIYAMA. M.. YAMASHITA. K. \& KIYOMOTO. A. (1975). Effect of diltiazem on electrical and mechanical activity of isolated cardiac ventricular muscle of guinea pig. Jap. J. Pharmac., 25, 383-392.

NAKAJIMA. H.. HOSHIYAMA. M.. YAMASHITA. K. \& KIYOMOTO. A. (1976). Electrical and mechanical responses to diltiazem in potassium depolarized myocardium of the guinea pig. Jap. J. Pharmac., 26, 571-580.

OHBA. M.. SAKAMOTO. Y. \& TOMITA. T. (1975). The slow wave in the circular muscle of the guinea-pig stomach. J. Physiol., 253, 505-516.

PEIPER. U. \& SCHMIDT. E. (1972). Relaxation of coronary arteries by electrochemical decoupling or adrenergic stimulation. Pflügers Arch. ges. Physiol., 337, 107-117.

ROUGIER. O.. VASSORT. G., GARNIER. D.. GARGOUIL. Y.M. \& CORABOEUF, E. (1968). Données nouvelles concernant le rôle des ions, $\mathrm{Na}^{+}$et $\mathrm{Ca}^{++}$sur properiétés électrophsiologiques des membranes cardiaque: existence dun canal lent. C.r. Acad. Sci. Paris, 226, 802-820.

SATO. M.. NAGANO. T.. YAMAGUCHI. I. NAKAJIMA, H. \& KIYOMOTO. A. (1971). Pharmacological studies on a new 1.5,-Benzothiazepine derivative (CRD-401). Arzneim-Forsch (Drug Res), 21, 1338-1343.

SOMLYO. A.P. \& SOMLYO. A.V. (1968). Vascular smooth muscle. 1. Normal structure, pathology, biochemistry and biophysics. Pharmac. Rev., 20, 197 272.

SU. C., BEVAN. J.A. \& URSILLO, R.C. (1964). Electrical quiescence of pulmonary artery smooth muscle during sympathetic stimulation. Circulation Res., 15, 20-27.

WEDER. U. \& GR ÜN. G. (1973). Ca ${ }^{++}$-antagonistische electromechanische Entkoppelung der glatten Gefässmuskulatur Nitroverbindungen. Naunyn Schmiedebergs Arch. Pharmac., 277 (suppl.): R. 88.

(Received October 25, 1977. Retised April 4, 1978.) 